\title{
The anaerobic digestion of pig carcase with or without sugar beet pulp, as a novel on-farm disposal method
}

by Kirby, M.E, Theodorou, M.K., Brizuela, C.M., Huntington, J.A., Powles, J. and Wilkinson, R.G.

Copyright, Publisher and Additional Information: This is the author accepted manuscript. The final published version (version of record) is available online via Elsevier.

This version is made available under the CC-BY-ND-NC licence:

https://creativecommons.org/licenses/by-nc-nd/4.0/legalcode

Please refer to any applicable terms of use of the publisher

DOI: https://doi.org/10.1016/j.wasman.2018.02.022

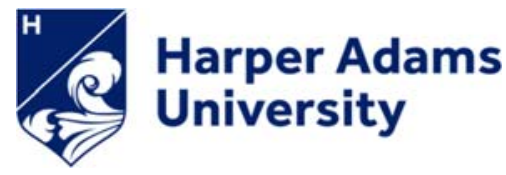

Kirby, M.E, Theodorou, M.K., Brizuela, C.M., Huntington, J.A., Powles, J. and Wilkinson, R.G. 2018. The anaerobic digestion of pig carcase with or without sugar beet pulp, as a novel on-farm disposal method. Waste Management. 
1 The anaerobic digestion of pig carcase with or without sugar beet pulp, as a novel on-

4 Marie E. Kirby ${ }^{a *}$, Michael K. Theodorou ${ }^{a}$, Carole M. Brizuela ${ }^{a}$, James A. Huntington ${ }^{\mathrm{a}}$,

$5 \quad$ Jayne Powles $^{\mathrm{a}}$ and Robert G. Wilkinson ${ }^{\mathrm{a}}$

6 * Corresponding author - telephone +44 (0) 1952 820280, fax +44 (0) 1952814783 ,

7 email address mkirby@harper-adams.ac.uk and postal address a Animal Production,

8 Welfare and Veterinary Sciences, Harper Adams University, Newport, Shropshire,

$9 \quad$ TF10 8NB, United Kingdom.

\section{Abbreviations}

12 Anaerobic digestion (AD), animal by-products (ABP), bovine spongiform

13 encephalopathy (BSE), colony-forming units (CFU), carbon:nitrogen ratio $(\mathrm{C}: \mathrm{N})$,

14 European Commission (EC), European Food Safety Authority (EFSA), feedstock (FS),

15 fresh weight $(\mathrm{FW})$, higher organic loading rate (-H), lower organic loading rate (-L),

16 mixed feedstock $(\mathrm{M})$, organic loading rate (OLR), pig carcase material (PCM), sugar

17 beet pulp (SBP), total solids (TS), United Kingdom (UK), volatile fatty acids (VFA),

18 volatile solids (VS).

\section{Abstract}

21 Anaerobic digestion was investigated as a potential method for on-farm disposal of

22 fallen stock (pig carcases), degrading the carcase material to produce biogas and

23 digestate. The effects of feedstock (sugar beet pulp or pig carcase material or a 50:50

24 mix) and organic loading rate $\left(50 \mathrm{~g}-\mathrm{TS} \mathrm{L}^{-1}\right.$ or $\left.100 \mathrm{~g}-\mathrm{TS} \mathrm{L}^{-1}\right)$, during mesophilic $\left(35^{\circ} \mathrm{C}\right)$ 
anaerobic digestion were investigated. Anaerobic digestion was achieved for all

experimental treatments, however the pig carcase material at the higher organic loading

27 rate produced the second highest methane yield $\left(0.56 \mathrm{Nm}^{3} \mathrm{~kg}_{\mathrm{VS}} \mathrm{VS}^{-1}\right.$ versus a range of

$28 \quad 0.14-0.58 \mathrm{Nm}^{3} \mathrm{~kg}-\mathrm{VS}^{-1}$ for other treatments), with the highest percentage of methane in

29 total biogas (61.6\% versus a range of $36.1-55.2 \%$ for all other treatments). Satisfactory

30 pathogen reduction is a legislative requirement for disposal of carcase material.

31 Pathogens were quantified throughout the anaerobic digestion process. Enterococcus

32 faecalis concentrations decreased to negligible levels (2.8 $\left.\log _{10} \mathrm{CFU} \mathrm{g}^{-\mathrm{TS}^{-1}}\right)$, whilst

33 Clostridium perfringens levels remained unaffected by treatment throughout the

34 digestion process $\left(5.3 \pm 0.2 \log _{10} \mathrm{CFU} \mathrm{g}^{-\mathrm{TS}^{-1}}\right)$.

35

36 Keywords - pig carcase; anaerobic digestion; animal by-product; carcase disposal;

$37 \quad$ fallen stock.

38

\section{$39 \quad 1.0$ Introduction}

40 In 2016, there were approximately 147 million pigs in Europe (Eurostat, 2017), with 4.4

41 million pigs (DEFRA, 2016) farmed in the United Kingdom (UK). Fallen stock are

42 defined as livestock which have died of natural causes or euthanised on-farm, and are

43 therefore not fit for human consumption. The average mortality rates on UK pig farms

44 are $5.4 \%$ sows, $12.2 \%$ pre-weanlings, $2.8 \%$ during rearing and $2.7 \%$ in the finishing

45 herd (AHDB Pork, 2016). This results in a substantial quantity of fallen stock annually

46 which requires safe, legal disposal. 
48 Traditionally, European livestock farmers disposed of fallen stock and animal by49 products (ABP) by on-farm open-burning and/or burial (Bansback, 2006). In 1984,

50 bovine spongiform encephalopathy (BSE) appeared in UK cattle (Bansback, 2006) and

51 in 1991, it was established that prions (the BSE causing agent) could remain infective

52 within the soil for up to 3 years following carcase burial (Brown and Gajdusek, 1991).

53 Subsequently, the ingestion of BSE-infected material was linked to the development of

54 variant Creutzfeldt-Jakob disease in humans (Fox and Peterson, 2004). In order to

55 reduce the risk of transmission within the cattle population and to humans, in 2002 the

56 Commission Regulation (European Commission (EC)) No. 1774/2002 prohibited on-

57 farm burning and burial for all fallen stock, irrespective of species susceptibility to

58 prion diseases. This legislation required farmers to use alternative methods of disposal;

59 either on-farm incineration, off-site incineration or off-site rendering. These methods (a)

60 increased the cost of fallen stock disposal to farmers, (b) raised concerns regarding their

61 negative environmental impact and (c) reduced farm biosecurity due to frequent

62 movement of potentially contaminated vehicles between farms and fallen stock

63 collection centres (Massé et al., 2008).

64

65 Kirby et al. (2010) surveyed UK livestock (dairy, beef, sheep and pig) farmers to assess

66 their compliance with EU fallen stock regulations and concluded that illegal disposal

67 occurred for $13.7 \%$ for fallen stock, $19.5 \%$ for aborted foetuses/stillborns and $57.6 \%$ for

68 placentas. The European Food Safety Authority (EFSA) provides scope for

69 consideration and approval of new/novel methods for carcase disposal and storage. For

70 a method to be considered, it must provide scientific evidence to demonstrate a 
71 sufficient reduction in disease risk (of $5.0 \log _{10}$ orders of magnitude), in specific key

72 animal and human health pathogens (EFSA, 2010).

73

74 Anaerobic digestion (AD) is commonly used to treat animal slurries, human sewage

75 (wastewater), municipal wastes and food wastes (Alvarez and Lidén, 2008). The AD

76 pasteurisation process can also destroy some pathogens (Escudero et al., 2014) and

77 subsequently if compliant with legislation, the pasteurised digestate can be applied to

78 agricultural land as a fertiliser/soil conditioner (Salminen and Rintala, 2002). In relation

79 to protein-rich feedstocks, a number of investigators have examined the feasibility of

80 using AD for the treatment of slaughterhouse wastes (Jensen et al., 2014 and Ortner et

81 al., 2015), specified risk material (potentially prion-infected spinal cord material)

82 (Gilroyed et al., 2010) and rendered ABP (Bayr et al., 2012). Carcase material and

83 slaughterhouse wastes are ideal substrates for AD due to the high contents of organic

84 matter, protein and lipids (Palatsi et al., 2011, Bayr et al., 2012). However, the digestion

85 of high protein content feedstocks can produce high ammonia and volatile fatty acids

86 (VFA) concentrations, which can inhibit biogas production (Sung and Lui, 2003 and

87 Nielsen et al., 2007). Moreover, carcase material differs from these previously

88 examined feedstocks, as complete carcases also contains bones, teeth and intestinal

89 content. Few authors have considered the possibility of using the AD process on-farm to

90 digest whole animal carcases. Massé et al. (2014) used AD at psychrophilic

91 temperatures $\left(20\right.$ and $\left.25^{\circ} \mathrm{C}\right)$ to successfully digested whole porcine carcases. Yuan et al.

92 (2012) digested carcase fractions, mixed with macerated carcase trimmings (without

93 intestinal contents) at mesophilic temperatures and demonstrated limited methane

94 yields. 
96 Anaerobic digestion is currently not an EFSA approved carcase disposal method as the

97 AD process conditions are unlikely to destroy prions. However, pigs and poultry are not susceptible to prion-infection via natural, oral infection routes (Ryder et al., 2000),

99 although experimental transmission can occur using artificial transmission routes

100 (intracranial, intravenous and intraperitoneal) (Groschup et al., 2007). Therefore, the

101 AD process may be a suitable method for on-farm disposal of pig and poultry carcases.

102 There is a research gap associated with the effective digestion of porcine carcases at 103 mesophilic temperatures, particularly where co-digestion with carbohydrate-rich

104 feedstocks are used to improve process stability and biogas yields. The objective of this

105 research was to investigate the potential of $\mathrm{AD}$ for the disposal of pig carcase material

106 (PCM), with and without sugar beet pulp (SBP) as an additional, highly-digestible

107 carbon source. To establish if the AD process would be a suitable novel method for

108 fallen stock on-farm, the research also investigated the potential for destruction of key

109 indicator pathogens (Enterococcus faecalis, Clostridium perfringens and Salmonella

110 spp), i.e., those described as pathogens in Commission Regulation (EC) No. 1774/2002

111 and Commission regulation (EC) No. 142/2011.

$113 \quad 2.0$ Materials and Methods

$114 \quad 2.1$ Reactor design

115 Six, cylindrical stainless steel bench-top AD reactors $(458 \mathrm{~mm}$ height, $210 \mathrm{~mm}$

116 diameter), each with a working volume of $10 \mathrm{~L}$ and head-space capacity of $2.6 \mathrm{~L}$ (total

117 volume 12.6L) were used for digestion studies. A schematic diagram of the exterior

118 surface and interior paddle stirrer configuration of a reactor is shown in Figure 1a and 
119 the reactors are shown photographically in Figure 1b. The reactors had 3 wall ports

120 spaced evenly down the cylindrical wall to allow digestate sampling from different

121 levels (top, middle and bottom). The head plate contained a feed port, sampling ports, a

122 gas nipple and a gas-tight paddle stirrer. The gas nipple permitted biogas from the

123 reaction vessel to be collected via tubing into a 5L capacity gas-tight Teflon bag

$124(35 \times 26.5 \mathrm{~cm})$ that was both sealable and detachable such that it could be removed for

125 gas analyses. When biogas production was excessive, more than 1 bag could be

126 connected to each reactor. Reactors were intermittently mixed (for fifteen minutes in

127 every hour, except during feeding) using a paddle stirrer connected to a direct current

128 motor (TGE 511, Denso, The Netherlands) that enabled complete vortex mixing at 30

129 rotations per minute. Reactors were heated using thermostatic regulators connected to

130 an externally insulated electric heating jacket which, except for the head plate and base,

131 completely covered the reaction vessel (Figure 1b).

132

$133 \quad 2.2$ Experimental design

134 The experiment was a $3 \times 2$ factorial block design repeated over 3 separate periods each

135 of 53 days duration. The 6 reactors were cleaned and reassembled between periods. The

136 effects of 6 individual treatments, comprising 3 feedstocks and 2 organic loading rates

137 (OLR), were investigated at mesophilic temperature $\left(34 \pm 2^{\circ} \mathrm{C}\right)$. Each treatment occurred

138 once in each period. The feedstocks were either SBP, PCM or a mixed (M) feedstock

139 containing 50:50 SBP:PCM on a w/w total solids (TS) basis. Reactors were fed on

140 alternate days during the feeding phase, with an OLR of either 50g-TS L-1 (low, -L) or

141 100g-TS L ${ }^{-1}$ (high, -H).

142 
143 Each 53-day period consisted of 3 discrete phases. The first phase was an

144 acclimatisation phase lasting for 3 days. At the start of this phase pre-heated reactors

145 were filled with 5L of fresh, non-pasteurised digestate taken from a typical commercial

146 mesophilic AD food waste plant. The purpose of the acclimatisation phase was to

147 ensure initial biogas production from the introduced digestate. The second phase, the

148 feeding phase, ran for 20 days post-acclimatisation. During the feeding phase, reactors

149 were fed once every 2 days receiving a total of 10 feeds. Each feed consisted of 25 or

$15050 \mathrm{~g}^{-\mathrm{TS}^{-1}}$ feedstock in $500 \mathrm{ml}$ with distilled water. Therefore, a total of 250 or $500 \mathrm{~g}-\mathrm{TS}^{-1}$

151 feedstock (in $10 \times 500 \mathrm{ml}$ aliquots) were fed to each reactor. The third phase of the

152 experiment was the non-feeding phase which ran for 30 days post-feeding. This non-

153 feeding phase was included to ensure EFSA requirements were met with regard to

154 carcase degradation and pathogen destruction, i.e., prior to emptying, the AD system

155 would need to be sealed for a specified period after the last carcase had been added.

$157 \quad 2.3$ Preparation of feedstocks

158 A whole gilt (approximately $50 \mathrm{~kg}$ ) was obtained from a commercial pig unit at the

159 University of Nottingham, slaughtered, quartered and frozen $\left(-20^{\circ} \mathrm{C}\right)$. The entire,

160 quartered carcase (including all organs and digesta contents) was macerated twice

161 (13mm then 4mm mincing plates) using a Wolfking type C-160 Universal grinder

162 (Boyd International Limited, Buckie, UK) and thoroughly mixed. Commercial SBP

163 animal feed was milled through a $2 \mathrm{~mm}$ diameter dry mesh screen (Christy \& Norris $8 "$

164 Laboratory \& Soil Mill, Ipswich, UK). For the purpose of description in this

165 manuscript, a feedstock is defined as the material that is fed to the reactor, whereas a

166 treatment refers to the combination of a feedstock and its organic loading rate. 


\subsection{Experimental routine (per period)}

169 The reactors were assembled and nitrogen was flushed through the feed port for 1

170 minute to remove oxygen (in air). Non-pasteurised AD digestate $(6 \times 5.5 \mathrm{~L}$ aliquots $)$ was

171 collected on the first day of the acclimatisation phase and a $500 \mathrm{ml}$ subsample was

172 removed from each aliquot for subsequent analyses. The remaining $5 \mathrm{~L}$ of digestate was

173 transferred immediately into 1 of the pre-warmed reactors; this process was repeated 5

174 more times to fill all reactors.

175

176 Following the acclimation phase, digestate samples were taken on day 1 of the feeding

177 phase (prior to the addition of feedstock) through the feed port on the head plate

178 (500ml). Subsequently feeding commenced (500ml aliquots) via the feed port and

179 continued every other day for a total of 10 feeds. Biogas volume and composition were

180 measured daily. Reactor temperature and $\mathrm{pH}$ were measured on the first day of the

181 feeding phase and subsequently on alternate days, via the feed port; these measurements

182 were made prior to addition of feedstock. At 10 day intervals (days 11, 21, 31, 41 and

183 51) a further $200 \mathrm{ml}$ sample was removed from the lower wall port of the reactor and

184 analysed for $\mathrm{pH}$, ammonium and VFA. Additional samples $(50 \mathrm{ml})$ were taken from the

185 same lower wall port at the start and end of the feeding phase and at the end of the non-

186 feeding phase and analysed for TS, volatile solids (VS) and enumeration of

187 Enterococcus faecalis, Clostridium perfringens and Salmonella spp. To calculate TS (g)

188 and VS (g) content of the digestate, reactors were weighed before the experiment

189 commenced (empty weight), at the end of the feeding phase and at the end of the

190 experiment. 
192 The three pathogens used in this experiment were chosen to comply with the 193 requirements of Commission Regulation (EC) No. 1774/2002, being infective to both 194 humans and animals. Commission regulation (EC) No. 142/2011 states that the 195 feedstock is pasteurised prior to or the digestate is pasteurised following the AD process $196\left(70^{\circ} \mathrm{C}\right.$ for 1 hour). However, Commission Regulation (EC) No. 1774/2002 states that 197 liquid material containing fallen stock and/or $\mathrm{ABP}$ should be sterilised $\left(133^{\circ} \mathrm{C}, 300 \mathrm{kPa}\right.$ 198 pressure for 20 minutes). To determine if pasteurisation or sterilisation would achieve 199 pathogen destruction, additional samples were taken for microbial counts at the end of 200 the non-feeding phase and either pasteurised or sterilised.

201

$202 \quad 2.5$ Chemical analyses

203 The volume of biogas collected in Teflon bags was measured using a dry test gas meter 204 (Shinagawa Corporation, Tokyo, Japan) and all gas volume data was normalised to $20520^{\circ} \mathrm{C}$ and 1 atmosphere. Methane composition was measured using a PGD3-IR infrared 206 portable gas analyser (Status Scientific Controls, Mansfield, England).

208 Digestate $\mathrm{pH}$ was measured using a $\mathrm{pH}$ probe (Jenway, UK) in conjunction with a 209 temperature probe; the reactor temperature was measured with a thermometer. Both $\mathrm{pH}$ 210 and temperature measurements were taken via the feed port in the head plate. The 211 ammonium concentration of the liquid digestate was measured using the Watson and 212 Galliher, (2001) methodology for Kjeldahl on a Foss Kjeltec 1035 sampler (FOSS, 213 Hillerød, Denmark). The VFA concentrations were determined using the method 214 described by Cruwys et al. (2002) on a Perkin Elmer Clarus 500 gas chromatograph 
215 fitted with a Nukol free fatty acid phase fused-silica capillary column $(30 \mathrm{~m} \times 0.25 \mathrm{~mm}$

216 ID, film thickness $0.25 \mu \mathrm{m}$, category number 24107, Supelco Ltd, Dorset, UK) (Cruwys

217 et al., 2002).

218

219 The TS (g) content of the feedstocks and digestate samples were determined using 220 freeze-drying (to constant weight), with the VS and carbon contents measured as a

221 percentage of the TS. The VS content was calculated as the weight of TS (g) lost

222 following ashing (at $550^{\circ} \mathrm{C}$ ) of the freeze dried sample overnight in a muffle furnace 223 (Carbolite, Hope Valley, England). The total carbon content was analysed using a 224 sulphur and carbon analyser, Leco SC-144 DR (LECO, Stockport, England) with 225 samples $(0.05 \mathrm{~g})$ weighed into a crucible boat of known weight and combusted at $2261000^{\circ} \mathrm{C}$. Total nitrogen (for carbon:nitrogen $(\mathrm{C}: \mathrm{N})$ ratios) was analysed using the Dumas 227 method (Watson and Galliher, 2001) on a nitrogen/protein Leco FP-528 (LECO, 228 Stockport, England). Crude protein was determined by multiplying the nitrogen content 229 (percentage of TS) by 6.25 (Jones, 1931). Ether extract content was measured by the 230 standard method for crude fat (Horwitz, 2000) using a Soxtec HT 1043 extraction unit

231 (FOSS, Hillerød, Denmark). All analysed values were adjusted for the daily calibration 232 against the appropriate calibration curve.

\section{$234 \quad 2.6$ Microbial analyses}

235 Analyses for pathogenic microorganisms were conducted at the Eclipse Scientific 236 Group laboratories (Telford, England) using the culture methods of detection for $E$.

237 faecalis (BS 4285 3.11.1985) (BSI, 1985), C. perfringens (BS EN ISO 7937:2004)

238 (BSI, 2004) and Salmonella spp. (BS EN ISO 6579:2002) (BSI, 2002). Bacterial 
239 numbers were enumerated as the number of colony-forming units (CFU) g-fresh weight

$240\left(\mathrm{FW}^{-1}\right)$ and converted to CFU g-TS ${ }^{-1}$ for each treatment. The data was transformed to

$241 \log _{10} \mathrm{CFU} \mathrm{g}_{\mathrm{TS}}{ }^{-1}$.

242

$243 \quad 2.7$ Statistical analyses

244 Data were analysed by ANOVA as a 3x2 factorial block design, main effects being

245 feedstock and OLR, with blocking through replicate (3 replicates per treatment).

246 Statistical analyses were conducted using GenStat version 17 with a significance level

247 of $\mathrm{P} \leq 0.05$, using Fisher's predicted least significant difference. Factorial ANOVA was

248 used to compare cumulative, biogas analyses data. For $\mathrm{pH}$, ammonium, VFA and

249 pathogen concentrations it was possible to analyse the data by ANOVA in two distinctly

250 different ways: either to investigate the treatment effects at each of the three time points

251 (days 1,21 and 51) both with and without covariate adjustment or by using repeated

252 measures analysis to investigate the behaviour of treatment effects over the time course

253 of the study. Both approaches were employed, but the repeated measures analysis was

254 considered the more meaningful, and is presented as the analysis of choice. The

255 rationale for this was because the antedependence ANOVA revealed that individual day

256 differences were influenced by the previous sampling date, rather than the effect of

257 treatment itself on each sampling date. This rendered analysis of data from individual

258 dates less appropriate.

259

$260 \quad 3.0$ Results and Discussion

2613.1 Treatment Chemical Composition 
262 The chemical composition of each feedstock and the feedstock formulation per

263 treatment are presented in Table 1. The crude protein contents for SBP and PCM were

264 reasonably similar to previously published values of $103 \mathrm{~g}-\mathrm{TS} \mathrm{L}^{-1}$ for SBP (Ziemiński et

265 al., 2012) and $375 \mathrm{~g}-\mathrm{kg}^{-1}$ for PCM (Whittemore and Kyriazakis, 2006).

266

$267 \quad 3.2$ Influence of treatment on reactor $\mathbf{p H}$ and ammonium concentrations

268 Table 2 records $\mathrm{pH}$ and ammonium concentrations over the time course of the 269 experiment. Related factors (time, feedstock, OLR) did not interact significantly to 270 influence the change in $\mathrm{pH}$ that was observed during the time course of the experiment

271 (Table 2). However, the pattern of $\mathrm{pH}$ change over time was statistically the same for

272 each of the six treatments tested (Table 2, $\mathrm{P}=0.002$ ). In each case, the $\mathrm{pH}$ declined from

273 the start of the experiment (mean 8.09) until the end of the feeding phase (mean 7.38),

274 before significantly increasing by the end of the experiment (mean 7.83). The pH values

275 at the end of the experiment were statistically the same as those on day 1 (Table 2).

276 There was also a significant main effect of feedstock across all time periods whereby

277 the non-porcine containing feedstock elicited a significantly $(\mathrm{P}=0.024)$ lower $\mathrm{pH}$ than

278 the two porcine containing feedstocks (Table 2). Declines in $\mathrm{pH}$ in AD reactors are

279 usually associated with increased acidity caused by the production of VFA by

280 acidogenic microorganisms in poorly buffered digestate (Wang et al., 2009). This was

281 particularly noticeable for the non-porcine containing treatments (SBP-H and SBP-L)

282 due to a combination of high carbohydrate and/or reduced protein contents, reducing the

283 buffering capacity compared to porcine containing treatments. 
285 For ammonium concentrations, related factors (time, feedstock, OLR) interacted

286 significantly $(\mathrm{P}<0.001)$ to influence the change in concentrations observed during the

287 time course of the experiment. Ammonium concentrations were statistically the same at

288 the start of the experiment (mean $3.02 \mathrm{~g} \mathrm{~L}^{-1}$ ). Thereafter, the pattern of change over time

289 and across all treatments was influenced to a large extent by the presence or absence of

290 porcine material in the treatment. During the feeding phase, ammonium concentrations

291 increased significantly in reactors fed porcine material (PCM-H, PCM-L, M-H),

292 whereas they declined significantly in the reactor receiving the lowest concentration of

293 porcine material (M-L) and the two SBP treatments (Table 2). Differences between the

294 extent of change in porcine containing treatments were also significant (PCM-H >

295 PCM-L = M-H > M-L). Corresponding ammonium concentrations in reactors fed

296 porcine containing material did not alter significantly during the non-feeding phase of

297 the experiment (Table 2). In the two reactors fed non-porcine containing treatments

298 (SBP-H, SBP-L), ammonium concentrations decreased significantly during the feeding

299 phase before increasing significantly by the end of the experiment (Table 2).

300 Ammonium concentrations in reactors fed these two treatments, at both day 21 and day

30151 of the experiment, were significantly lower than the concentrations accumulating in

302 reactors fed all other treatments (Table 2). There was also a significant main effect of

303 feedstock across all time periods which showed that the two porcine containing

304 feedstocks accumulated significantly higher ammonium concentrations than the SBP

305 feedstock $(\mathrm{P}=0.001)$ according to the relationship ( $\mathrm{PCM}=\mathrm{M}>\mathrm{SBP}$ ) (Table 2). As was

306 to be expected, there was an exceptionally good linear relationship between feedstock

307 protein content and reactor ammonium concentrations (Figure 2). The linear

308 relationship demonstrates that carcase protein hydrolysis, particularly at the higher 
309 OLR, was not limited by other physiological factors or treatment characteristics. This

310 effect was also noted by Resch et al. (2011) when digesting ABP.

311

312 Protein is most effectively degraded to ammonium at neutral $\mathrm{pH}$ (Shu-guang et al.,

313 2007), with digestion stability dependent upon the C:N ratio of the feedstock and its

314 subsequent buffering capacity. Chen et al. (2008) described an optimum C:N ratio of

315 20:1. The C:N ratios for feedstocks used in the current work ranged from SBP 25:1, M

$316 \quad$ 10:1 and PCM 7:1 (Table 1). High protein feedstocks can enhance reactor buffering

317 capacity, as production of ammonium from protein degradation increases $\mathrm{pH}$ (Escudero

318 et al., 2014). Sugar beet pulp had a low nitrogen content (Table 1) so could not buffer

319 against the $\mathrm{pH}$ decreased caused by the accumulating VFA concentrations. In keeping

320 with these results, Shu-guang et al. (2007) working on the dry mesophilic AD of high

321 protein (25\%) and carbohydrate (28\%) dog food also noted a similar $\mathrm{pH}$ decrease (due

322 to the high rate of VFA production) and subsequent increase in $\mathrm{pH}$. Ammonium levels

323 for all six treatments were comparable to the combined ammonium and soluble

324 ammonia concentrations of 1.7-5.7 $\mathrm{g} \mathrm{L}^{-1}$ published by Edström et al. (2003) for the

325 digestion of animal slurries and slaughterhouse wastes, with SBP feedstock containing a

326 lower protein content displaying the lowest yields of Edström et al. (2003).

$328 \quad 3.3$ Influence of treatment on reactor volatile fatty acid concentration

329 Throughout the experiment, acetic acid was the most abundant VFA for all treatments,

330 followed by substantially lower concentrations of propionic and remaining acids

331 (butyric and valeric) (Table 3). In general, the pattern of VFA change was similar over

332 time and across all treatments. Lower levels of VFA $\left(0.4-1.0 \mathrm{~g} \mathrm{~L}^{-1}\right.$ acetic acid; $0.05-0.11$ 
$333 \mathrm{~g} \mathrm{~L}^{-1}$ propionic acid; 0.12-0.24 $\mathrm{g} \mathrm{L}^{-1}$ remaining acids) at the start of the experiment

334 accumulated by day 21 to higher levels (4.7-9.3 $\mathrm{g} \mathrm{L}^{-1}$ acetic acid; $0.42-2.95 \mathrm{~g} \mathrm{~L}^{-1}$

335 propionic acid; $0.77-2.71 \mathrm{~g} \mathrm{~L}^{-1}$ remaining acids). Thereafter, VFA concentrations

336 declined and by the end of the experiment levels were similar to those recorded at day 1

337 (Table 3). There was one notable exception to the general response. In reactors fed with

338 the SBP-H treatment, VFA concentrations increased both during the feeding phase and

339 non-feeding phase of the experiment (Table 3). With the exclusion of the SBP-H

340 treatment, the range of VFA concentrations at day 51 were not dissimilar to those

341 recorded at the start of the experiment (0.1-0.4 $\mathrm{g} \mathrm{L}^{-1}$ acetic acid; 0.04-0.13 $\mathrm{g} \mathrm{L}^{-1}$

342 propionic acid; $0.11-0.39 \mathrm{~g} \mathrm{~L}^{-1}$ remaining acids). Statistical analysis revealed that

343 related factors (time, feedstock, OLR) interacted significantly $(\mathrm{P}<0.001)$ to influence the

344 change in VFA concentrations during the time course of the experiment. The pattern of

345 VFA change across all treatment showed significant increases $(\mathrm{P}<0.001)$ for most VFA

346 concentrations to the end of the feeding phase. However, there were three exceptions;

347 butyric and valeric acid concentrations (i.e., the remaining acids in Table 3 ) from

348 reactors fed SBP-L, PCM-L and M-L treatments, while increased, were not significantly

349 different to day 1 values (Table 3). Thereafter, and in all but one treatment (SBP-H),

350 VFA concentrations declined significantly or, for the three exceptions mentioned above,

351 remained unaltered; at the end of the experiment they were not significantly different

352 the values recorded on day 1.

354 3.4 Influence of treatment on reactor biogas production

355 The biogas accumulation profiles for all treatments during the time course of the

356 experiment are shown in Figure 3. All treatments resulted in biogas production. Biogas 
357

358

359

360

361

362

363

364

365

366

367

368

369

370

371

372

373

374

375

376

377

378

379

380

accumulated linearly during the feeding phase of the experiment, except for SBP-H where the gas profile began to plateau before the end of the feeding phase. Thereafter, the rate of gas accumulation slowed and tended towards a plateau (Figure 3). Table 4 records biogas and methane yields and the percentage of methane in biogas at the endpoints (51 days) of the gas accumulation profiles. Feedstock and OLR interacted significantly to influence the total biogas yield for each treatment (Table 4). Unlike the $\mathrm{pH}$ and VFA interactions, it was not possible to distinguish absolutely between porcine and non-porcine containing treatments on the basis of their total biogas yields. The two feedstocks containing just porcine material produced the significantly $(\mathrm{P}<0.001)$ highest total biogas yields (PCM-L>PCM-H). Treatments M-H, M-L and SBP-L produced significantly lower but similar total biogas yields $(M-H=M-L=S B P-L)$ and the SBP-H treatment produced the lowest total biogas yield (Table 4).

Methane yields from each treatment were also influenced by feedstock and OLR but to a lesser extent than total biogas yields (Table 4). It was therefore possible to segregate treatments on the basis of porcine containing feedstocks. These four treatments resulted in the production of significantly higher methane values than the two treatments that contained just SBP (Table 4). For porcine containing treatments, the two treatments containing just porcine material (PCM-L and PCM-H) produced similar but significantly $(\mathrm{P}=0.031)$ higher methane yields than the two mixed treatments ( $\mathrm{M}-\mathrm{L}$ and $\mathrm{M}-\mathrm{H})$, which were similar to each other but significantly lower than the porcine only treatments. Moreover, the two treatments which contained the higher OLR in the porcine grouping (PCM-H and M-H) were also similar to each other (Table 4). 
381 The percentage of methane in biogas was calculated for each of the three replicates for

382 each treatment. It was possible to distinguish between porcine containing and non-

383 porcine containing treatments on the basis of the percentage of methane in biogas. The

384 four porcine containing treatments resulted in the production of biogas with

385 significantly $(\mathrm{P}=0.018)$ greater methane percentage than the two SBP treatments, with

386 SBP-L having significantly greater percentage of methane in biogas than SBP-H (Table

387 4). The percentage of methane in the biogas for PCM-H (61.6\%) was significantly

$388(\mathrm{P}=0.018)$ greater than for the other three porcine containing treatments which were

389 similar to each other (range 53.7-55.2\%; Table 4).

390

391 In general, while interactions were apparent, the results presented in Table 4 can be

392 summarised to show that feedstocks containing just SBP produced significantly lower

393 biogas and methane yields with significantly lower methane percentage in biogas than

394 the four porcine containing treatments. Where SBP was mixed with porcine material,

395 (M-H and M-L), this resulted in a reduction (often significant) in the yield of gases and

396 in the methane percentage in comparison to the treatments that contained just porcine

397 material (PCM-L and PCM-H). Thus, while PCM-H produced the greatest yield of

398 biogas, PCM-L produced significantly less biogas but with a significantly higher

399 methane percentage. These results can be contrasted to those obtained for acetic acid

400 production (Table 3) where five of the treatments resulted in levels of acetic acid (the

401 principal methanogenic pre-cursor) that were not different from each other but were

402 lower than the yield produced by the SBP-H. Nielsen et al. (2007) demonstrated a

403 similar increase in VFA concentrations, decrease in $\mathrm{pH}$ and reduction in methane 
404 production due to the increased feeding rate of SBP, inhibiting methanogens and

405 causing an unstable digestion process (Wang et al., 2009).

406

407 The percentage of methane in total biogas for the four porcine containing treatments 408 ranged from 53.7-61.6\% (Table 4). These values were slightly lower than those 409 obtained for mesophilic digestion of slaughterhouse waste (66-69\%) (Ortner et al., 410 2015). However the methane yields were considerably higher for PCM containing 411 treatments (range $0.44-0.58 \mathrm{Nm}^{3} \mathrm{~kg}-\mathrm{VS}^{-1}$ ) compared to previously published data of $4120.36 \mathrm{~m}^{3} \mathrm{~kg}_{-\mathrm{VS}}{ }^{-1}$ for cattle manure and potentially prion-infected spinal cord material at a 413 lower OLR of $30 \mathrm{~g}-\mathrm{VS} \mathrm{L}^{-1}$ (Gilroyed et al., 2010); the mono-digestion of pig blood of $414 \quad 0.44-0.48 \mathrm{Nm}^{3} \mathrm{~kg}^{-\mathrm{VS}^{-1}}$; pig intestinal contents of $0.45-0.66 \mathrm{Nm}^{3} \mathrm{~kg}^{-\mathrm{VS}^{-1}}$ and grease 415 separation of $0.43-0.50 \mathrm{Nm}^{3} \mathrm{~kg}-\mathrm{VS}^{-1}$ (Ortner et al., 2015). Additionally, the methane 416 yield for PCM containing feedstock was higher than the excepted methane yields for 417 food waste $0.27 \mathrm{~m}^{3} \mathrm{~kg}-\mathrm{VS}^{-1}$ and for garden waste $0.53 \mathrm{~m}^{3} \mathrm{~kg}^{-\mathrm{VS}^{-1}}$ (Browne et al., 2014). 418

3.5 Influence of the AD process on the persistence of Clostridium perfringens, 420 Enterococcus faecalis and Salmonella spp.

421 Although Salmonella spp. are found within carcases and are often associated with food 422 poisoning (Côté et al., 2006), they were not detected in any of the samples taken from 423 the bench-top $\mathrm{AD}$ reactors.

424

425 For E. faecalis, related factors (time, feedstock, OLR) did not interact significantly $426(\mathrm{P}>0.050)$ to influence the change in CFU counts observed during the time course of the 427 experiment (Table 5). E. faecalis was detected on days 1 and 21 of the experiment. 
428 There was a marginal decrease in CFU counts across all treatments by day 21 but the

429 numbers detected at the end of the acclimatisation and feeding phases (day 1 and 21)

430 were not significantly different. By the end of the non-feeding phase (day 51) CFU

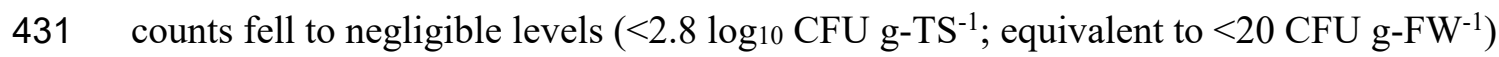

432 for all treatments, demonstrating that sufficient time had elapsed under unfavourable

433 conditions and with no further addition of $E$. faecalis during the non-feeding phase to

434 destroy known concentrations (Table 5). Consequently, due to their negligible

435 concentration at day 51, it was not possible to quantify the effect of pasteurisation and

436 sterilisation on E. faecalis populations. EFSA (2010) requires a $5.0 \log _{10}$ reduction in

437 specific pathogens for the pathogen destruction process to be deemed safe. However

438 due to insufficient natural occurrence of $E$. faecalis in digestate samples, while AD was

439 clearly effective, it was not possible to achieved the required reduction in population

440 numbers.

442 For C. perfringens, related factors (time, feedstock, OLR) did not interact significantly

$443 \quad(\mathrm{P}<0.001)$ to influence the change in CFU counts observed during the time course of the

444 experiment (Table 5). C. perfringens were detected on days 1, 21, 51 of the experiment

445 and after the pasteurisation but not the sterilisation procedures. The CFU counts for $C$.

446 perfringens from all treatments remained unaltered throughout the experiment but a

447 significant decrease $(\mathrm{P}<0.001)$ of just $1 \log _{10}$ unit in population numbers occurred

448 following pasteurisation of the digestate (Table 5). Clostridium can form spores which

449 are resistant to heat inactivation (Sahlström et al., 2008). Pasteurisation was not

450 therefore effective at destroying C. perfringens to the $5.0 \log _{10}$ reduction level required

451 by Commission regulation (EC) No. 142/2011. These results confirm the previous 
452 findings of Sahlström et al. (2008) where sporulation of C. perfringens occurred

453 following pasteurisation of digestate at $70^{\circ} \mathrm{C}$ for 1 hour. However, when day 51 samples

454 were sterilised $\left(133^{\circ} \mathrm{C}, 300 \mathrm{kPa}\right.$ pressure for 20 minutes $)$, C. perfringens detection levels

455 were negligible $\left(<2.5 \log _{10} \mathrm{CFU} \mathrm{g}^{-\mathrm{TS}^{-1}}\right.$; equivalent to $<10 \mathrm{CFU}$ g-FW $\left.{ }^{-1}\right)$ (Table 5).

456 Sterilisation was therefore effective in meeting Commission regulation (EC) No.

457 142/2011. The average main effect across all time periods (including pasteurisation)

458 showed a significantly higher $(\mathrm{P}=0.044)$ concentration of $C$. perfringens in the

459 feedstock containing just SBP, compared to porcine containing feedstocks (Table 5).

460 These significances in CFU counts were marginal, possibly suggesting that $C$.

461 perfringens survived the pasteurisation process to a moderately greater extend in

462 feedstocks that did not contain porcine material (Table 5).

463

464 Overall, the results presented suggest that the natural abundance of microorganisms in 465 the initial digestate and their development over time was not sufficient to demonstrate 466 the EFSA required $5.0 \log _{10}$ reduction for the development of a novel storage method 467 for fallen pigs (Commission regulation (EC) No. 142/2011). Similarly, Costa et al. 468 (2017) also demonstrated a reduction in pathogen concentration within animal slurries 469 and digestate during storage, but natural pathogen concentration was not great enough 470 to demonstrate the required EFSA $5.0 \log _{10}$ reduction.

471

472 3.6 Suitability of the AD process in relation to policy

473 Anaerobic digestion of PCM potentially provides a sustainable alternative method for 474 the disposal of fallen pigs. This research has demonstrated that PCM can be digested 475 anaerobically to produce methane, with and without an additional carbon source such as 
476 SBP. Methane yields were significantly higher $(\mathrm{P}=0.031)$ for treatments PCM-L and

477 PCM-H (Table 4; mean $0.57 \mathrm{Nm}^{3} \mathrm{~kg}^{-\mathrm{VS}^{-1}}$ ) and according to the literature, were

478 substantially higher than mixed cattle/pig slaughterhouse waste $\left(0.06 \mathrm{~m}^{3} \mathrm{~kg}-\mathrm{VS}^{-1}\right)$ or

479 fruit and vegetable wastes $\left(0.45 \mathrm{~m}^{3} \mathrm{~kg} \mathrm{VS}^{-1}\right)($ Ortner et al., 2015). Digestion of SBP was

480 not ideal, as biogas yields were lowest for feedstock SBP and biogas yields for M-H

481 were reduced in comparison to PCM-L, which contained the same quantity of carcase

482 material (Table 4). Therefore any future research digesting carcase material would not

483 benefit from co-digestion with SBP.

484

485 In relation to pathogen destruction, E. faecalis was destroyed to negligible levels by the

486 end of the experiment, however C. perfringens concentrations remained at unacceptable

487 levels throughout the experiment. Commission Regulation (EC) No. 1774/2002 requires

488 a $5.0 \log _{10}$ reduction of pathogens (Commission Regulation (EC) No. 1774/2002) for a

489 novel method to be approved. Therefore further research is needed using pathogen

490 spiked AD reactors to known pathogen concentrations to enable the observation of $>5.0$

$491 \log _{10}$ reduction in pathogen numbers. Additionally pre- and post-treatment processes

492 could be investigated (see Commission regulation (EC) No. 142/2011) to help achieve

493 the required $5.0 \log _{10}$ reductions for key pathogens.

494

495 Potential benefits of using AD for the disposal of pig carcases include the fact that the

496 digester would need to be emptied less frequently compared to the current, frequent

497 collection (almost daily) methods for fresh/stored carcases. Reducing collection

498 frequency would improve the farm's biosecurity (Massé et al., 2008), as there would be

499 fewer vehicle movements onto the farm which could spread disease. Additionally, the 
500 biogas could be converted into electricity or heat to be used on-farm, further reducing

501 farm costs. Based upon the methane yields from the PCM-H treatment, if the methane 502 was combusted under 1 standard atmosphere at $25^{\circ} \mathrm{C}$ with $100 \%$ engine efficiency, it

503 would produce $6.8 \mathrm{kWh} \mathrm{kg-VS}{ }^{-1}$. Further research would be required to optimise the

504 digestion process, using both pre- and post-treatment of PCM, to determine the effects

505 this has upon the destruction of key pathogens required by EFSA. Pilot scale trials

506 would then have to be conducted on-farm with the full operational and safety

507 requirements completed.

508

$509 \quad 4.0$ Conclusion

510 This research demonstrates that PCM can be effectively digested at $35^{\circ} \mathrm{C}$ with and

511 without a carbon source, to produce significant quantities of total biogas with methane

512 concentrations ranging from 40.3-67.5\%. The treatment PCM-H (100g-TS L $\left.{ }^{-1}\right)$ was the

513 most suitable treatment in relation to process stability and biogas yield, producing

$5140.85 \mathrm{Nm}^{3} \mathrm{~kg}-\mathrm{VS}^{-1}$ total biogas and $0.56 \mathrm{Nm}^{3} \mathrm{~kg}^{-\mathrm{VS}^{-1}}$ methane (Table 4). Addition of

515 carbon, in the form of SBP, was not necessary to successfully digest PCM at these

516 OLR. Naturally occurring populations of Salmonella spp., E. faecalis and C.

517 perfringens on these feedstocks were not sufficiently large to permit verification of

518 EFSA requirements for alternative disposal methods. In the case of $C$. perfringens, due

519 to the survival of heat-tolerant spores, it was evident that pasteurisation alone did not

520 present a suitable method for pathogen destruction. Further research is therefore

521 required to investigate pathogen destruction both pre- and post-AD processing of PCM, 522 prior to pilot scale AD trials on porcine farms.

523 


\section{Acknowledgements}

525 Financial support was provided by Agricultural and Horticulture Development Board,

526 Pork Division (Kenilworth, UK) and Harper Adams University to fund this research.

527 Special thanks are given to Dr Mewa S. Dhanoa for statistical advice and to Mr John

528 Chapman, Miss Tracey Lewis and the laboratory staff at Harper Adams University for

529 their help with the laboratory analyses. Kirby, Brizuela, Huntington, Powles and

530 Wilkinson designed and carried out the experiment and analysed the results, whilst

531 Kirby and Theodorou conducted the statistical analyses, drafted and revised the 532 manuscript.

533

\section{References}

535 AHDB Pork., 2016. The BPEX yearbook 2015-2016. AHDB Pork.

536 Alvarez, R., Lidén, G., 2008. Semi-continuous co-digestion of solid slaughterhouse

537 waste, manure and fruit and vegetable waste. Renew. Energy, 33, 726-34.

538 Bansback, B., 2006. Independent review of the National Fallen Stock Scheme and

539 company. DEFRA. Accessed $28^{\text {th }}$ April 2014.

540 http://webarchive.nationalarchives.gov.uk/20070216120000/http:/www.defra.gov.uk/an

541 imalh/by-prods/pdf/nfsco-review.pdf

542 Bayr, S., Rantanen, M., Kaparaju, P., Rintala, J., 2012. Mesophilic and thermophilic

543 anaerobic co-digestion of rendering plant and slaughterhouse wastes. Bioresour.

544 Technol., 104, 28-36.

545 Brown, P., Gajdusek, D.C., 1991. Survival of scrapie virus after 3 years internment.

546 Lancet, 337, 269-70. 
547 Browne, J.D., Allen, E., Murphy, J.D., 2014. Assessing the variability in biomethane

548 production from the organic fraction of municipal solid waste in batch and continuous

549 operation. Appl. Energy, 128, 307-14.

550 BSI., 1985. BS4285: Microbiological examination for dairy purposes. Methods for

551 detection and/or enumeration of specific groups of microorganisms. Detection and

552 enumeration of faecal streptococci. London: BSI.

553 BSI., 2002. BS6579: Microbiology of food and animal feeding stuffs - Horizontal

554 method for the detection of Salmonella spp. London: BSI.

555 BSI., 2004. BS7937: Microbiology of Food and Animal Feeding Stuffs. Horizontal

556 Method for the Enumeration of Clostridium Perfringens. Colony-count Technique.

557 London: BSI.

558 Chen, Y., Cheng, J.J., Creamer, K.S., 2008. Inhibition of anaerobic digestion process: a

559 review. Bioresour. Technol., 99, 4044-64.

560 Costa, A., Gusmara, C., Gardoni, D., Zaninelli, M., Tambone, F., Sala, V. and Guarino,

561 M. 2017. The effect of anaerobic digestion and storage on indicator microorganisms in

562 swine and dairy manure. Environ. Sci. Pollut. Res., 24, 24135-24146.

563 Commission regulation (EC) No. 1774/2002 of the European parliament and of the

564 council of 3 October 2002 laying down health rules concerning animal by-products not 565 intended for human consumption. Official J. of the European Union, L 273/1.

566 Commission regulation (EC) No. 142/2011 of 25 February 2011 implementing

567 Regulation (EC) No 1069/2009 of the European Parliament and of the Council laying

568 down health rules as regards animal by-products and derived products not intended for

569 human consumption and implementing Council Directive 97/78/EC as regards certain 
570 samples and items exempt from veterinary checks at the border under that Directive.

571 Official J. of the European Union, L 54/1.

572 Côté, C., Masse, D.I., Quessy, S., 2006. Reduction of indicator and pathogenic

573 microorganisms by psychrophilic anaerobic digestion in swine slurries. Bioresour.

574 Technol., 97, 686-691.

575 Cruwys, J.A., Dinsdale, R.M., Hawkes, F.R., Hawkes, D.L., 2002. Development of a

576 static headspace gas chromatographic procedure for the routine analysis of volatile fatty

577 acids in wastewaters. J. Chromatogr., 945, 195-209.

578 DEFRA., 2016. Farming Statistics - Livestock Populations at 1 December 2015.

579 DEFRA. Accessed $3^{\text {rd }}$ January 2017.

580 https://www.gov.uk/government/uploads/system/uploads/attachment_data/file/508230/s

581 tructure-dec2015-uk-17mar16.pdf

582 Edström, M., Norberg, Å., Thyselius, L., 2003. Anaerobic treatment of animal by-

583 products from slaughterhouses at laboratory and pilot scale. Appl. Biochemistry and

584 Biotechnology, 109, 127-38.

585 EFSA., 2010. Statement on technical assistance on the format for applications for new

586 alternative methods for animal by-products. EFSA.

587 Escudero, A., Lacalle, A., Blanco, F., Pinto, M., Díaz, I., Domínguez, A., 2014. Semi-

588 continuous anaerobic digestion of solid slaughterhouse waste. J. of Environmental

589 Chemical Engineering, 2, 819-25.

590 Eurostat., 2017. Number of pigs. Eurostat. Accessed 26 th July 2017.

591 http://ec.europa.eu/eurostat/tgm/table.do?tab=table\&init $=1 \&$ language $=$ en $\& p$ code $=\operatorname{tag} 00$

$592 \quad \underline{018 \& \text { plugin }=1}$ 
593 Fox, J.A., Peterson, H.H., 2004. Risks and implications of bovine spongiform

594 encephalopathy for the United States: insights from other countries. Food Policy, 29, $595 \quad 45-60$.

596 Gilroyed, B.H., Reuter, T., Chu, A., Hoa, X., Weiping, X., McAllister, T.A., 2010.

597 Anaerobic digestion of specified risk material with cattle manure for biogas production.

598 Bioresour. Technol., 101, 5780-5.

599 Groschup, M.H., Hörnlimann, B., Buschmann, A., 2007. Iatrogenic and "natural"

600 transmissibility of prion diseases. In: Hörnlimann, B., Riesner, D., Kretzschmar, H. eds.

601 Prions in humans and animals. New York: De Gruyter. pp. 483-98.

602 Horwitz, W., 2000. Official methods of analysis of AOAC International. Gaithersburg,

603 USA: Association of Analytical Communities.

604 Jensen, P.D., Sullivan, T., Carney, C., Batstone, D.J., 2014. Analysis of the potential to

605 recover energy and nutrient resources from cattle slaughterhouses in Australia by

606 employing anaerobic digestion. Appl. Energy, 136, 23-31.

607 Jones, D.B., 1931. Factors for converting percentages of nitrogen in foods and feeds

608 into percentages of protein. USDA (US Department of Agriculture) Circular Series,

$609183,1-21$.

610 Kirby, M., Brizuela, C., Wilkinson, R., 2010. Investigation of farmers' perspectives on

611 the disposal of fallen livestock and animal by-products in Great Britain. Vet. Rec., 167,

$612 \quad 606-9$.

613 Massé, D.I., Masse, L., Hince, J.F., Pomar, C., 2008. Psychrophilic anaerobic digestion

614 biotechnology for swine mortality disposal. Bioresour. Technol., 99, 7307-11. 
615 Massé, D.I., Rajagopal, R., Singh, G., 2014. Technical and operational feasibility of

616 psychrophilic anaerobic digestion biotechnology for processing ammonia-rich waste.

617 Appl. Energy, 120, 49-55.

618 Nielsen, H.B., Uellendahl, H., Ahring, B.K., 2007. Regulation and optimization of the

619 biogas process: propionate as a key parameter. Biomass Bioenergy, 31, 820-30.

620 Ortner, M., Wöss, D., Schumergruber, A., Pröll, T., Fuchs, W., 2015. Energy self-

621 supply of large abattoir by sustainable waste utilization based on anaerobic mono-

622 digestion. Appl. Energy, 143, 460-71.

623 Palatsi, J., Viñas, M., Guivernau, M., Fernandez, B., Flotats, X., 2011. Anaerobic

624 digestion of slaughterhouse waste: Main process limitations and microbial community

625 interactions. Bioresour. Technol., 102, 2219-27.

626 Resch, C., Wörl, A., Waltenberger, R., Braun, R., Kirchmayr, R., 2011. Enhancement

627 options for the utilisation of nitrogen rich animal by-products in anaerobic digestion.

628 Bioresour. Technol., 102, 2503-10.

629 Ryder, S.J., Hawkins, A.C., Dawson, M., Wells, G.A.H., 2000. The neuropathy of

630 experimental bovine spongiform encephalopathy in the pig. J. of Comparative

631 Pathology, 122, 131-43.

632 Sahlström, L., Bagge, E., Emmoth, E., Holmqvist, A., Danielsson-Tham, M.L., Albihn, 633 A., 2008. A laboratory study of survival of selected microorganisms after heat treatment 634 of biowaste used in biogas plants. Bioresour. Technol., 99, 7859-65.

635 Salminen, E.A., Rintala, J.A., 2002. Anaerobic digestion of organic solid poultry 636 slaughterhouse waste - a review. Bioresour. Technol., 83, 13-26. 
637 Shu-guang, L., Tsuyoshi, I., Masao, U., Masahiko, S., 2007. Start-up performances of

638 dry anaerobic mesophilic and thermophilic digestions of organic solid wastes. J. of

639 Environmental Sciences, 19, 416-20.

640 Sung, S., Lui, T., 2003. Ammonia inhibition on thermophilic anaerobic digestion.

641 Chemosphere, 53, 43-52.

642 Wang, Y., Zhang, W., Wang, J., Meng, L., 2009. Effects of volatile fatty acid

643 concentrations on methane yield and methanogenic bacteria. Biomass Bioenergy, 33,

$644 \quad 848-53$.

645 Watson, M.E., Galliher, T.L., 2001. Comparison of dumas and kjeldahl methods with

646 automatic analyzers on agricultural samples under routine rapid analysis conditions.

647 Communication in Soil Sci. and Plant Analysis, 32, 2007-19.

648 Whittemore, C., Kyriazakis, I., 2006. Whittemore's science and practice of pig

649 production. Oxford: Blackwell Publishing.

650 Yuan, Q., Saunders, S.E., Bartelt-Hunt, S.L., 2012. Methane and carbon dioxide

651 production from simulated anaerobic degradation of cattle carcasses. Waste

652 Management, 32, 939-43.

653 Ziemiński, K., Romanowska, I., Kowalska, M., 2012. Enzymatic pretreatment of

654 lignocellulosic wastes to improve biogas production. Waste Management, 32, 1131-37.

655

656

\section{$\underline{\text { Table and Figure Captions }}$}

657 Table 1 Chemical composition of the feedstocks; sugar beet pulp and pig carcase

658 material, and feedstock formulations

659 Table 2 The effect of feedstock and organic loading rate on repeated measures of $\mathrm{pH}$

660 and ammonium concentration $\left(\mathrm{g} \mathrm{L}^{-1}\right)$ throughout the experiment 
661 Table 3 The effect of feedstock and organic loading rate on repeated measures of net

662 volatile fatty acid concentrations $\left(\mathrm{g} \mathrm{L}^{-1}\right)$ throughout the experiment

663 Table 4 The effect of feedstock and organic loading rate on cumulative total biogas and

664 methane yields $\left(\mathrm{Nm}^{3} \mathrm{~kg}-\mathrm{VS}^{-1}\right)$ and methane $(\%)$ of total biogas

665 Table 5 The effect of feedstock and organic loading rate on split-plot analysis of

666 variance of Enterococcus faecalis and repeated measures of Clostridium perfringens

667 concentrations $\left(\log _{10} \mathrm{CFU} \mathrm{g-TS}^{-1}\right)$ at the end of the acclimatisation, feeding and non-

668 feeding phases; for the non-feeding determinations, measurements were made on

669 samples pre- and post-pasteurisation and moist heat sterilisation

670 Figure 1a Schematic diagram of the exterior surface and internal paddle stirrer

671 configuration of the 12.6 litre anaerobic reactors

672 Figure 1b Photograph of the six operating reactors

673 Figure 2 Linear relationship between the total crude protein content fed to reactors $(\mathrm{g})$

674 and accumulated ammonium concentration $\left(\mathrm{g} \mathrm{L}^{-1}\right)$ in reactors, at day 21 and 51, across

675 all treatments

676 Figure 3 The effect of feedstock and organic loading rate on total biogas yield $\left(\mathrm{Nm}^{3} \mathrm{~kg}\right.$ -

$677 \mathrm{VS}^{-1}$ ) throughout the experiment. Values presented are cumulative, 5-day summations.

678 The SEM across all 5-day summations ranged from 0.01-0.10. 


\begin{tabular}{|c|c|c|c|c|c|c|}
\hline Chemical compositions $\left(\mathrm{g} \mathrm{kg}^{-1}\right)$ & & $\underline{\text { SBP }}$ & & & $\underline{\mathrm{PCM}}$ & \\
\hline Total solids & & 866.7 & & & 337.2 & \\
\hline Volatile solids & & 766.4 & & & 315.1 & \\
\hline Total carbon & & 400.8 & & & 569.6 & \\
\hline Total nitrogen & & 16.0 & & & 76.9 & \\
\hline Crude protein & & 100.0 & & & 480.6 & \\
\hline Ether extract & & 6.6 & & & 403.2 & \\
\hline Feedstock formulations (g) & $\underline{\text { SBP-L }}$ & $\underline{\text { SBP-H }}$ & $\underline{\text { PCM-L }}$ & $\underline{\mathrm{PCM}-\mathrm{H}}$ & $\underline{\mathrm{M}-\mathrm{L}}$ & $\underline{\mathrm{M}-\mathrm{H}}$ \\
\hline Fresh weight & 291 & 582 & 736 & 1472 & 513 & 1026 \\
\hline Total solids & 252 & 504 & 248 & 496 & 250 & 500 \\
\hline Volatile solids & 228 & 456 & 227 & 454 & 228 & 456 \\
\hline Volume of water (ml) & 4709 & 4418 & 4264 & 3529 & 4487 & 3973 \\
\hline Total carbon & 101 & 202 & 141 & 282 & 121 & 242 \\
\hline Total nitrogen & 4 & 8 & 19 & 38 & 12 & 24 \\
\hline Ether extract & 2 & 4 & 97 & 194 & 49 & 98 \\
\hline Carbon:nitrogen ratio & $25: 1$ & $25: 1$ & $7: 1$ & $7: 1$ & $10: 1$ & $10: 1$ \\
\hline
\end{tabular}

680 Feedstocks: SBP, sugar beet pulp; PCM, pig carcase material; M, mixed (50\%:50\% SBP: PCM). Feedstock formulations (organic loading 681 rate): -L, Low 50 g-TS L-1; -H, High $100 \mathrm{~g}^{-T S ~ L^{-1}}$.

682

683

684 


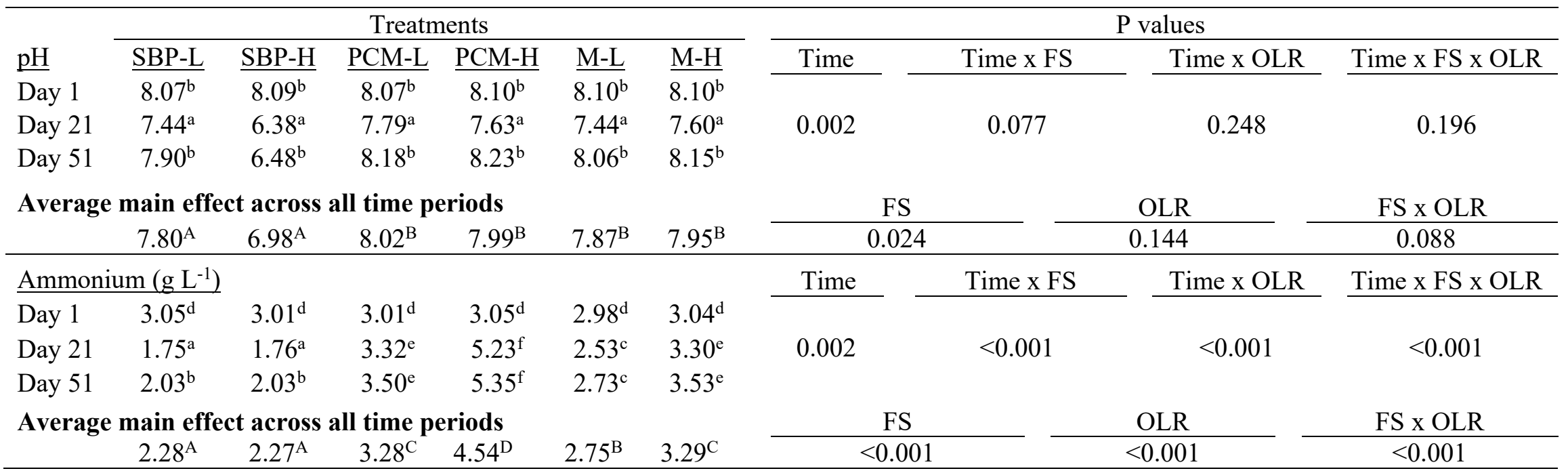

Repeated measurement analysis (split-plot-in time) over all time points. Numerator and denominator degrees of freedom were scaled by the Greenhouse-Geisser epsilon before calculating F-ratio probability. FS, Feedstocks: SBP, sugar beet pulp; PCM, pig carcase material; M, mixed (50\%:50\% SBP: PCM). Feedstock formulations (OLR, organic loading rate): -L, Low 50 g-TS L-1; -H, High 100 g-TS L-1 Day 1 (end of the acclimatisation phase), day 21 (end of the feeding phase) and day 51 (end of the non-feeding phase). Mean data interactions in columns and rows (lower case superscripts) and average treatment data in rows (upper case superscripts) with the same superscript are not 


\begin{tabular}{|c|c|c|c|c|c|c|c|c|c|c|}
\hline \multirow{2}{*}{$\frac{\text { Acetic acid }}{\left(\mathrm{g} \mathrm{L}^{-1}\right)}$} & \multicolumn{6}{|c|}{ Treatments } & \multicolumn{4}{|c|}{$\mathrm{P}$ value } \\
\hline & $\underline{\text { SBP-L }}$ & $\underline{\text { SBP-H }}$ & $\underline{\mathrm{PCM}-\mathrm{L}}$ & PCM-H & $\underline{\mathrm{M}-\mathrm{L}}$ & $\underline{\mathrm{M}-\mathrm{H}}$ & Time & Time $\mathrm{x} F \mathrm{~F}$ & Time $\mathrm{x}$ OLR & Time $x$ FS x OLR \\
\hline Day 1 & $0.8^{\mathrm{a}}$ & $0.8^{\mathrm{a}}$ & $0.8^{\mathrm{a}}$ & $0.5^{\mathrm{a}}$ & $1.0^{\mathrm{a}}$ & $0.4^{\mathrm{a}}$ & & & & \\
\hline Day 21 & $4.7^{\mathrm{b}}$ & $9.3^{\mathrm{c}}$ & $5.6^{\mathrm{b}}$ & $5.9^{\mathrm{b}}$ & $4.7^{\mathrm{b}}$ & $5.1^{\mathrm{b}}$ & $<0.001$ & 0.001 & 0.002 & 0.002 \\
\hline Day 51 & $0.2^{\mathrm{a}}$ & $11.5^{\mathrm{d}}$ & $0.1^{\mathrm{a}}$ & $0.4^{\mathrm{a}}$ & $0.1^{\mathrm{a}}$ & $0.1^{\mathrm{a}}$ & & & & \\
\hline \multicolumn{7}{|c|}{ Average main effect across all time periods } & \multicolumn{2}{|c|}{ FS } & OLR & FS x OLR \\
\hline & $1.9^{\mathrm{A}}$ & $7.2^{\mathrm{B}}$ & $2.2^{\mathrm{A}}$ & $2.3^{\mathrm{A}}$ & $1.9^{\mathrm{A}}$ & $1.9^{\mathrm{A}}$ & \multicolumn{2}{|c|}{$<0.001$} & $<0.001$ & $<0.001$ \\
\hline \multicolumn{7}{|c|}{ Propionic acid $\left(\mathrm{g} \mathrm{L}^{-1}\right)$} & Time & Time $\mathrm{x}$ FS & Time $\mathrm{x}$ OLR & Time $x$ FS x OLR \\
\hline Day 1 & $0.11^{\mathrm{a}}$ & $0.06^{\mathrm{a}}$ & $0.05^{\mathrm{a}}$ & $0.07^{\mathrm{a}}$ & $0.05^{\mathrm{a}}$ & $0.05^{\mathrm{a}}$ & & & & \\
\hline Day 21 & $0.42^{\mathrm{b}}$ & $2.95^{\mathrm{d}}$ & $0.42^{\mathrm{b}}$ & $2.51^{\mathrm{c}}$ & $0.59^{\mathrm{b}}$ & $2.30^{\mathrm{c}}$ & $<0.001$ & $<0.001$ & $<0.001$ & $<0.001$ \\
\hline Day 51 & $0.05^{\mathrm{a}}$ & $3.73^{\mathrm{e}}$ & $0.05^{\mathrm{a}}$ & $0.13^{\mathrm{a}}$ & $0.05^{\mathrm{a}}$ & $0.04^{\mathrm{a}}$ & & & & \\
\hline \multicolumn{7}{|c|}{ Average main effect across all time periods } & \multicolumn{2}{|c|}{ FS } & OLR & FS x OLR \\
\hline & $0.19^{\mathrm{A}}$ & $2.24^{\mathrm{C}}$ & $0.17^{\mathrm{A}}$ & $0.91^{\mathrm{B}}$ & $0.23^{\mathrm{A}}$ & $0.80^{\mathrm{B}}$ & \multicolumn{2}{|c|}{$<0.001$} & $<0.001$ & $<0.001$ \\
\hline \multicolumn{7}{|c|}{$\underline{\text { Remaining acids (butyric and valeric) }\left(\mathrm{g} \mathrm{L}^{-1}\right)}$} & Time & Time $\mathrm{x} F \mathrm{~F}$ & Time $\mathrm{x}$ OLR & Time $x$ FS $x$ OLR \\
\hline Day 1 & $0.24^{\mathrm{a}}$ & $0.24^{\mathrm{a}}$ & $0.22^{\mathrm{a}}$ & $0.24^{\mathrm{a}}$ & $0.23^{\mathrm{a}}$ & $0.12^{\mathrm{a}}$ & & & & \\
\hline Day 21 & $0.77^{\mathrm{a}}$ & $1.77^{\mathrm{b}}$ & $0.79^{\mathrm{a}}$ & $2.71^{\mathrm{c}}$ & $0.80^{\mathrm{a}}$ & $1.67^{\mathrm{b}}$ & $<0.001$ & $<0.001$ & $<0.001$ & $<0.001$ \\
\hline Day 51 & $0.11^{\mathrm{a}}$ & $3.89^{\mathrm{d}}$ & $0.11^{\mathrm{a}}$ & $0.39^{\mathrm{a}}$ & $0.11^{\mathrm{a}}$ & $0.11^{\mathrm{a}}$ & & & & \\
\hline \multicolumn{7}{|c|}{ Average main effect across all time periods } & \multicolumn{2}{|c|}{ FS } & OLR & FS x OLR \\
\hline & $0.37^{\mathrm{A}}$ & $1.97^{\mathrm{C}}$ & $0.37^{\mathrm{A}}$ & $1.11^{\mathrm{B}}$ & $0.38^{\mathrm{A}}$ & $0.63^{\mathrm{AB}}$ & \multicolumn{2}{|c|}{0.022} & $<0.001$ & 0.022 \\
\hline
\end{tabular}

Repeated measurement analysis (split-plot-in time) over all time points. Numerator and denominator degrees of freedom were scaled by the Greenhouse-Geisser epsilon before calculating F-ratio probability. FS, Feedstocks: SBP, sugar beet pulp; PCM, pig carcase material; M, mixed (50\%:50\% SBP: PCM). Feedstock formulations (OLR, organic loading rate): -L, Low 50 g-TS L-1; -H, High 100 g-TS L-1. Day 1 (end of the acclimatisation phase), day 21 (end of the feeding phase) and day 51 (end of the non-feeding phase). Mean data interactions in columns and rows (lower case superscripts) and average treatment data in rows (upper case superscripts) with the same superscript are not significantly different $(\mathrm{P}>0.050)$. 


\begin{tabular}{|c|c|c|c|c|c|c|c|c|c|}
\hline \multirow[b]{2}{*}{ Biogas produced $\left(\mathrm{Nm}^{3} \mathrm{~kg}_{-} \mathrm{VS}^{-1}\right)$} & \multicolumn{6}{|c|}{ Treatments } & \multicolumn{3}{|c|}{$P$ value } \\
\hline & SBP-L & SBP-H & PCM-L & $\underline{\mathrm{PCM}-\mathrm{H}}$ & $\underline{\mathrm{M}-\mathrm{L}}$ & $\underline{\mathrm{M}}-\mathrm{H}$ & FS & OLR & FS x OLR \\
\hline Biogas yield & $0.72^{b}$ & $0.33^{\mathrm{a}}$ & $0.97^{\mathrm{d}}$ & $0.85^{\mathrm{c}}$ & $\overline{0.74^{\mathrm{b}}}$ & $\overline{0.77^{\mathrm{b}}}$ & $<0.001$ & $<0.001$ & $<0.001$ \\
\hline Methane yield & $0.33^{\mathrm{b}}$ & $0.14^{\mathrm{a}}$ & $0.58^{\mathrm{e}}$ & $0.56^{\mathrm{de}}$ & $0.44^{\mathrm{c}}$ & $0.46^{\mathrm{cd}}$ & $<0.001$ & 0.039 & 0.031 \\
\hline Methane $(\%)$ in biogas & $42.5^{\mathrm{b}}$ & $36.1^{\mathrm{a}}$ & $53.7^{\mathrm{c}}$ & $61.6^{\mathrm{d}}$ & $54.1^{\mathrm{c}}$ & $55.2^{\mathrm{c}}$ & $<0.001$ & 0.540 & 0.018 \\
\hline
\end{tabular}

710 FS, Feedstocks: SBP, sugar beet pulp; PCM, pig carcase material; M, mixed (50\%:50\% SBP: PCM). Feedstock formulations (OLR, 711 organic loading rate): -L, Low $50 \mathrm{~g}-\mathrm{TS} \mathrm{L}^{-1} ;-\mathrm{H}$, High $100 \mathrm{~g}-\mathrm{TS} \mathrm{L}^{-1}$. Mean data in rows with the same superscript are not significantly 712 different $(\mathrm{P}>0.050)$. 


\begin{tabular}{|c|c|c|c|c|c|c|c|c|c|c|}
\hline \multirow{2}{*}{$\frac{\frac{\text { Enterococcus }}{\text { faecalis }\left(\log _{10} \mathrm{CFU}\right.}}{\left.\mathrm{g}_{\mathrm{TS}} \mathrm{TS}^{-1}\right)}$} & \multicolumn{6}{|c|}{ Treatments } & \multicolumn{4}{|c|}{$\mathrm{P}$ value } \\
\hline & $\underline{\text { SBP-L }}$ & $\underline{\text { SBP-H }}$ & $\underline{\text { PCM-L }}$ & $\underline{\text { PCM-H }}$ & $\underline{\mathrm{M}-\mathrm{L}}$ & $\underline{\mathrm{M}-\mathrm{H}}$ & Time & Time $x$ FS & Time $x$ OLR & Time $x$ FS x OLR \\
\hline Day 1 & 6.1 & 6.1 & 6.4 & 6.1 & 6.1 & 6.2 & \multirow{2}{*}{0.701} & \multirow{2}{*}{0.317} & \multirow{2}{*}{0.967} & \multirow{2}{*}{0.579} \\
\hline Day 21 & 6.0 & 5.8 & 5.4 & 5.6 & 5.5 & 5.2 & & & & \\
\hline Day 51 & $\mathrm{~N}$ & $\mathrm{~N}$ & $\mathrm{~N}$ & $\mathrm{~N}$ & $\mathrm{~N}$ & $\mathrm{~N}$ & - & - & - & - \\
\hline Pasteurised day 51 & $\mathrm{~N}$ & $\mathrm{~N}$ & $\mathrm{~N}$ & $\mathrm{~N}$ & $\mathrm{~N}$ & $\mathrm{~N}$ & - & - & - & - \\
\hline Sterilised day 51 & $\mathrm{~N}$ & $\mathrm{~N}$ & $\mathrm{~N}$ & $\mathrm{~N}$ & $\mathrm{~N}$ & $\mathrm{~N}$ & - & - & - & - \\
\hline \multicolumn{7}{|c|}{ Average main effect across all time periods } & \multicolumn{2}{|c|}{ FS } & OLR & FS $x$ OLR \\
\hline & 6.1 & 5.9 & 5.9 & 5.8 & 5.8 & 5.7 & \multicolumn{2}{|c|}{0.492} & 0.481 & 0.989 \\
\hline \multicolumn{7}{|c|}{ Clostridium perfringens $\left(\log _{10} \mathrm{CFU}_{\mathrm{g}} \mathrm{TS}^{-1}\right)$} & Time & Time $\mathrm{x}$ FS & Time $\mathrm{x}$ OLR & Time $\mathrm{x}$ FS $\times$ OLR \\
\hline Day 1 & $5.8^{\mathrm{b}}$ & $5.9^{\mathrm{b}}$ & $5.9^{\mathrm{b}}$ & $5.7^{\mathrm{b}}$ & $5.4^{\mathrm{b}}$ & $5.7^{\mathrm{b}}$ & \multirow{4}{*}{$<0.001$} & \multirow{4}{*}{0.769} & \multirow{4}{*}{0.792} & \multirow{5}{*}{0.949} \\
\hline Day 21 & $5.8^{\mathrm{b}}$ & $6.0^{\mathrm{b}}$ & $5.5^{\mathrm{b}}$ & $5.4^{\mathrm{b}}$ & $5.9^{\mathrm{b}}$ & $5.6^{\mathrm{b}}$ & & & & \\
\hline Day 51 & $5.3^{\mathrm{b}}$ & $5.5^{\mathrm{b}}$ & $5.3^{\mathrm{b}}$ & $5.4^{b}$ & $5.4^{\mathrm{b}}$ & $5.1^{\mathrm{b}}$ & & & & \\
\hline Pasteurised day 51 & $5.1^{\mathrm{a}}$ & $4.6^{\mathrm{a}}$ & $4.3^{\mathrm{a}}$ & $4.0^{\mathrm{a}}$ & $4.3^{\mathrm{a}}$ & $4.1^{\mathrm{a}}$ & & & & \\
\hline Sterilised day 51 & $\mathrm{~N}$ & $\mathrm{~N}$ & $\mathrm{~N}$ & $\mathrm{~N}$ & $\mathrm{~N}$ & $\mathrm{~N}$ & - & - & - & \\
\hline \multicolumn{7}{|c|}{ Average main effect across all time periods, including pasteurised day 51} & \multicolumn{2}{|c|}{ FS } & OLR & FS x OLR \\
\hline & $5.5^{\mathrm{B}}$ & $5.5^{\mathrm{B}}$ & $5.2^{\mathrm{A}}$ & $5.1^{\mathrm{A}}$ & $5.3^{\mathrm{A}}$ & $5.1^{\mathrm{A}}$ & \multicolumn{2}{|c|}{0.044} & 0.420 & 0.812 \\
\hline
\end{tabular}

Repeated measurement analysis (split-plot-in time) for Clostridium perfringens over all time points. Numerator and denominator degrees of freedom are scaled by the Greenhouse-Geisser epsilon before calculating F-ratio probability. FS, Feedstocks: SBP, sugar beet pulp; PCM, pig carcase material; M, mixed (50\%:50\% SBP: PCM). Feedstock formulations (OLR, organic loading rate): $-\mathrm{L}$, Low 50 g-TS L-1; - $\mathrm{H}$, High $100 \mathrm{~g}-T S ~ L^{-1}$. Day 1 (end of the acclimatisation phase), day 21 (end of the feeding phase) and day 51 (end of the non-feeding phase). Mean data interactions in columns and rows (lower case superscripts) and average treatment data in rows (upper case superscripts) with the same superscript are not significantly different $(\mathrm{P}>0.050)$. Pasteurised samples were held at $70^{\circ} \mathrm{C}$ for 1 hour and sterilised samples were held at $133^{\circ} \mathrm{C}$ for 20 minutes at $300 \mathrm{kPa}$ pressure. Colony-forming unit (CFU) counts that were negligible (N) equated to $<20 \mathrm{CFU}^{-} \mathrm{g}^{-\mathrm{FW}} \mathrm{N}^{-1}$ $\left(<2.8 \log _{10} \mathrm{CFU} \mathrm{g}_{\mathrm{TSS}}{ }^{-1}\right)$ for Enterococcus faecalis and $<10 \mathrm{CFU} \mathrm{g-F^{-1 }}\left(<2.5 \log _{10} \mathrm{CFU} \mathrm{g}^{-\mathrm{TS}^{-1}}\right)$ for Clostridium perfringens. 

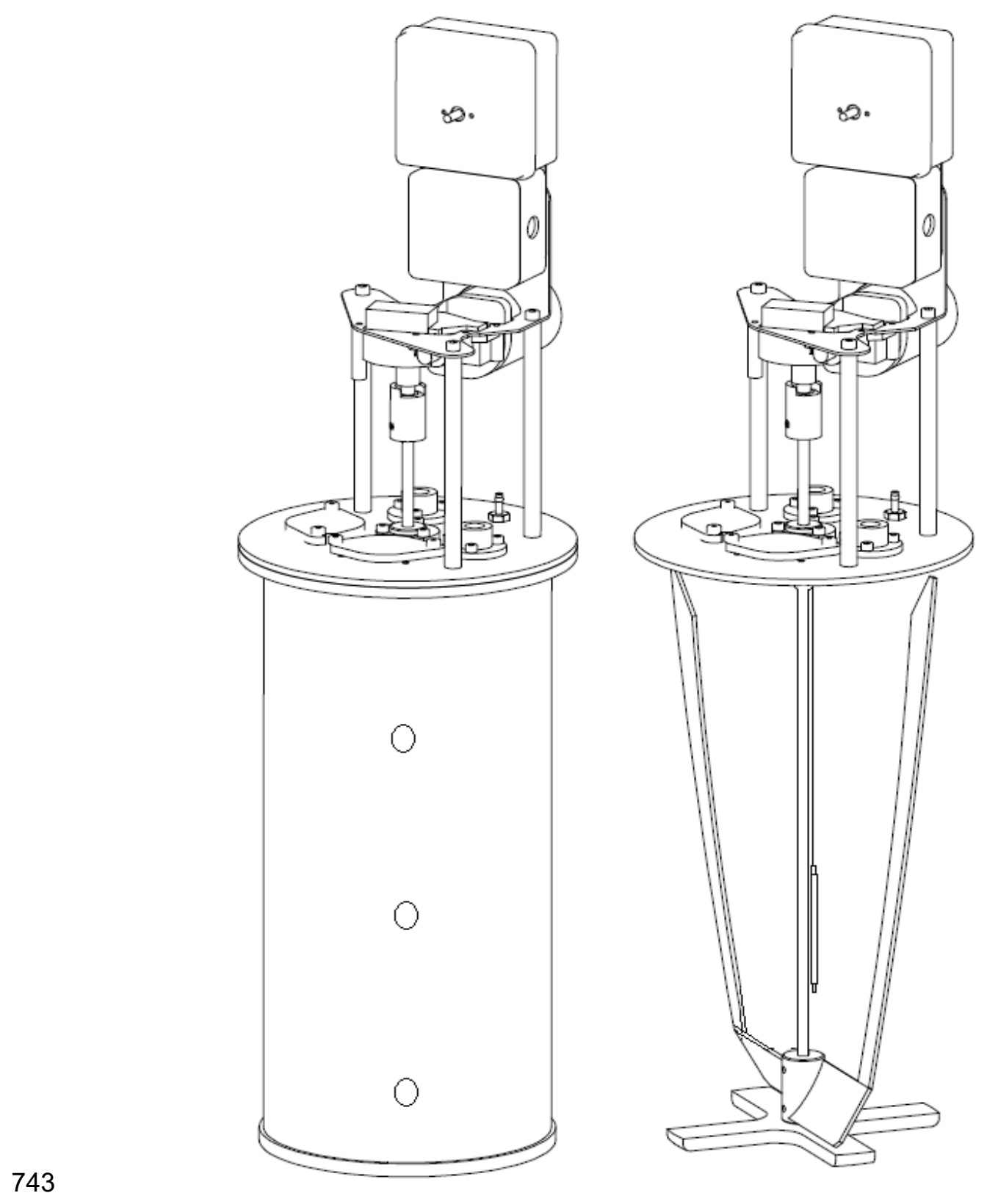

$744 \quad$ Figure 1a

745

746

747

748

749 


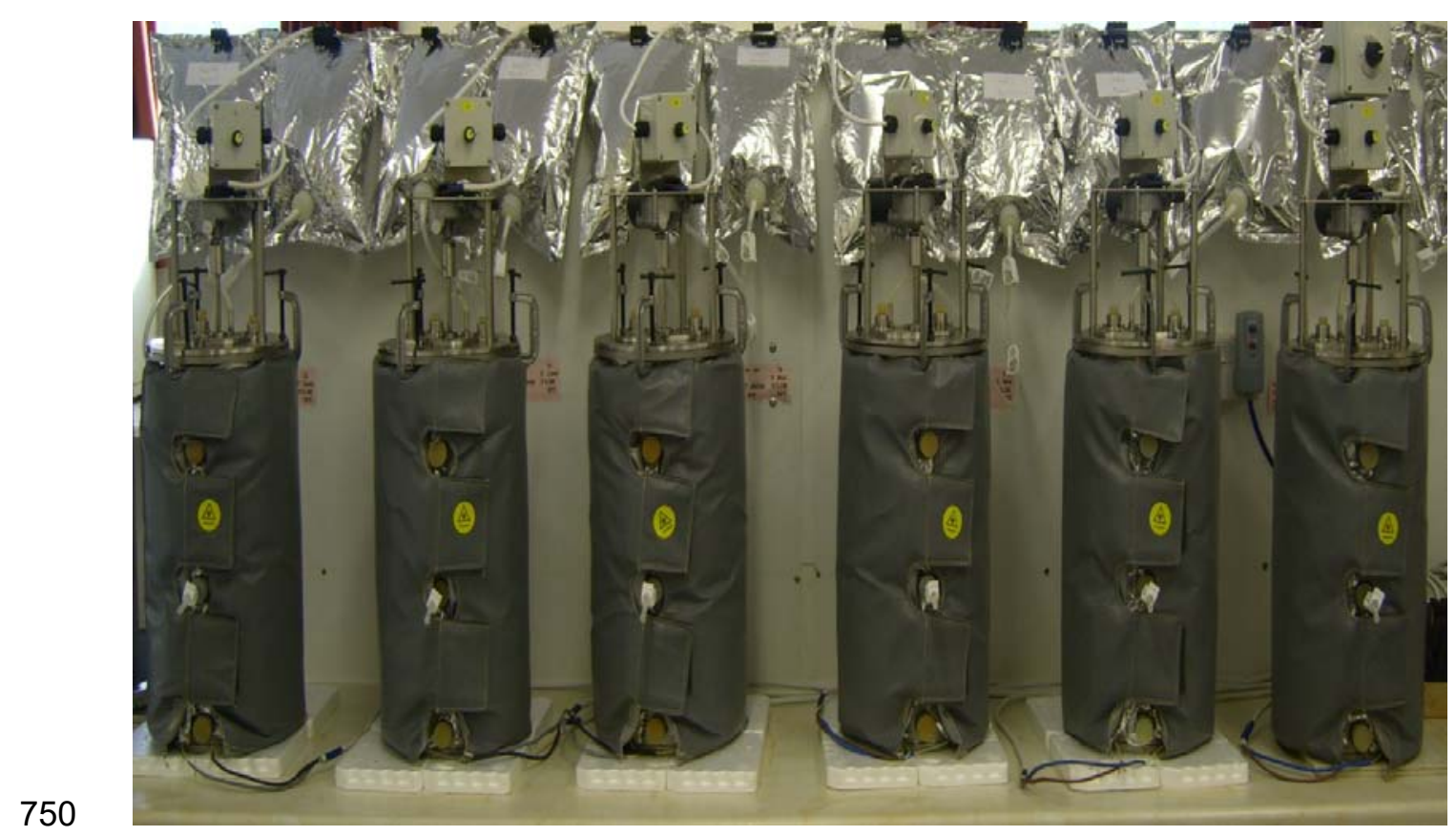

751 Figure $1 b$ 


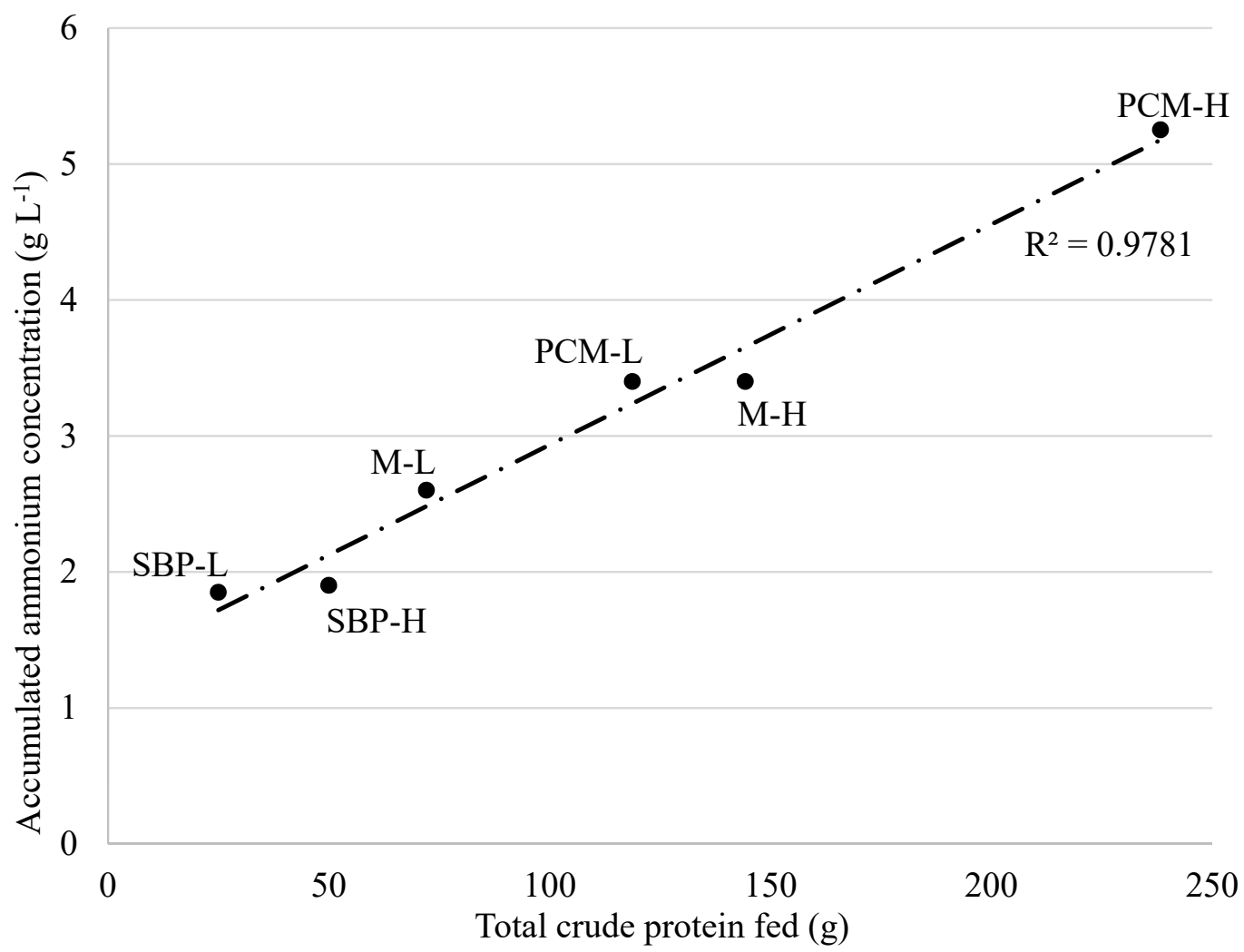

Figure 2

754 Feedstocks: SBP, sugar beet pulp; PCM, pig carcase material; M, mixed (50\%:50\%

755 SBP: PCM). Feedstock formulations (OLR, organic loading rate): -L, Low $50 \mathrm{~g}-\mathrm{TS} \mathrm{L}^{-1}$; $756-\mathrm{H}$, High $100 \mathrm{~g}-\mathrm{TS} \mathrm{L}{ }^{-1}$. 


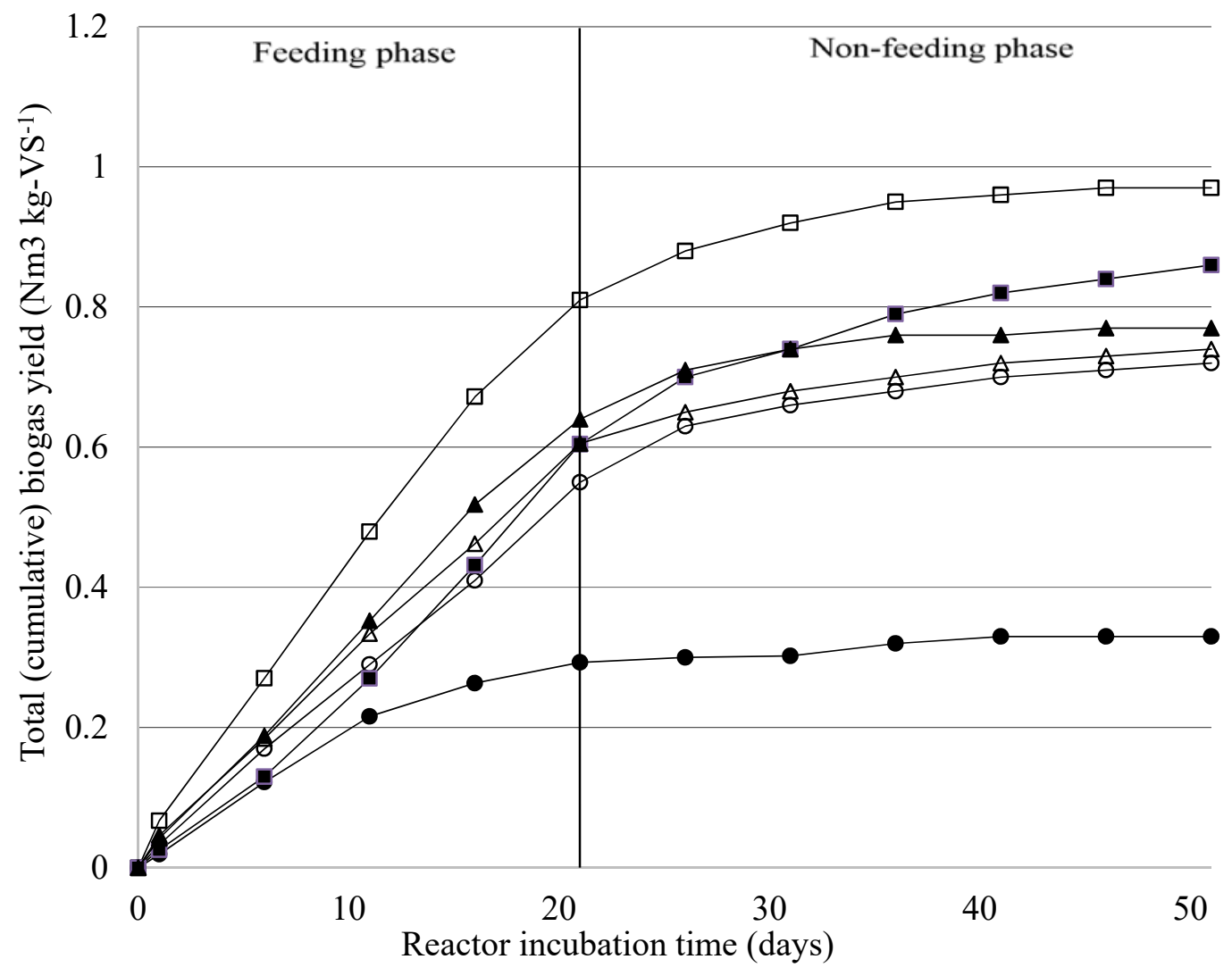

757 Figure 3

758 Feedstocks: SBP, sugar beet pulp; PCM, pig carcase material; M, mixed (50\%:50\%

759 SBP: PCM). Feedstock formulations (OLR, organic loading rate): -L, Low 50 g-TS L-1, 760 -H, High 100 g-TS L ${ }^{-1}$. Symbols: ○ SBP-L, • SBP-H, $\square$ PCM-L, — PCM-H, $\Delta$ M-L and 761 \ M-HL.

762 